\title{
Records of Tengmalm's Owl (Aegolius funereus) from the Šar Mts, Republic of Macedonia
}

\author{
Peter Shurulinkov ${ }^{1}$, Dimiter Avtanski ${ }^{2}$
}

1 National Museum of Natural History, Bulgarian Academy of Sciences, 1 Tsar Osvoboditel Blvd, 1000 Sofia, Bulgaria, p.shurulinkov@gmail.com

2 Friedman Diabetes Institute, Northwell Health, New York, 10022 New York, USA

\begin{abstract}
Three localities of the Tengmalm's owl (Aegolius funereus) were recorded during a field trip in the Šar Mts, Northwestern Republic of Macedonia. The study was conducted in October, 2015. The species was found to inhabit spruce and spruce-fir forests at altitudes between 1436 and $1848 \mathrm{~m}$ a.s.l. That finding is the first evidence of the presence of the Tengmalm's owl in the Macedonian part of the Šar Mts and one of the very few published records for the occurrence of the species in the Republic of Macedonia.
\end{abstract}

Keywords: Aegolius funereus, spruce forest, Šar Mts, Macedonia

Tengmalm's Owl (Aegolius funereus L.) is a glacial relict, sparsely distributed in the high mountain coniferous and mixed forests on the Balkan Peninsula. Recently, its distribution and habitat preferences were studied quite intensively in that region, especially in Bulgaria, Serbia and Slovenia (Vrezeć, 2003; Shurulinkov \& Stoyanov, 2006; Rajković et al., 2010; Shurulinkov et al., 2012; Rajković et al., 2013). There are no specific studies on this species, specifically on its distribution, in the Republic of Macedonia, Albania, Bosnia and Montenegro. Thus, we visited the Šar Mts, North-western Republic of Macedonia, looking for Tengmalm's owls. According to the available sources, the forest belt of that mountain offers quite appropriate habitats for the species: spruce and beech forests at altitudes between 1500 and $2000 \mathrm{~m}$ a.s.l. Until now, there is no published information about the presence of the Tengmalm's owl in the Macedonian part of the Šar Mts, despite the fact that there are ornithofaunistic studies conducted in the forest belt of that mountain and neighbouring forested areas (Delić, 1948; Trilar, 1985; Kajevska et al., 1996; Velevski et al., 2002; Micevski, 2010; Velevski et al., 2010).

We visited two main areas of the Šar Mts during an ornithological expedition in the period 2126.10.2015. Firstly, we studied the coniferous forests at the upper tree limit in the area above the Popova Shapka ski complex and close to the former Jelak Hut. There was a massif of about 350 ha of coniferous forests, mostly spruce, not very old. Afterwards, we visited a coniferous (spruce-fir) forest massif of 210 ha in a part of the southern Šar Mountains, in the valley of Adzhina River. We made 2.5-3 km long evening and night transects, in spruce, spruce-beech and beech-fir forests of different age. We used mp3 player for voice provocation of the Tengmalm's owl. Imitations of the mating song of the species were produced at each $550-700 \mathrm{~m}$ of the route. At each stop point we played the sound for up to $15 \mathrm{~min}$, with 2-3 short pauses (about 1 min each).

Three positive answers of Tengmalm's owls were registered at three locations. Firstly, on 23.10.2015, we heard the species alarm call "tsjalp" 6-7 times at 18:45 (local time) in the vicinity of the former Jelak Hut (nowadays burnt) after 10 min of sound imitation. The habitat around consisted of 60-70 years old spruce forest on the north-eastern slope with some meadows at $1848 \mathrm{~m}$ a.s.l. The weather was cloudy, $2-3^{\circ} \mathrm{C}$, with light NE breeze. The next two records of the Tengmalm's owl were made in the southern Šar Mts, in the valley of the Adzhina River, in the evening on 24.10.2015. At the first location one Tengmalm's 


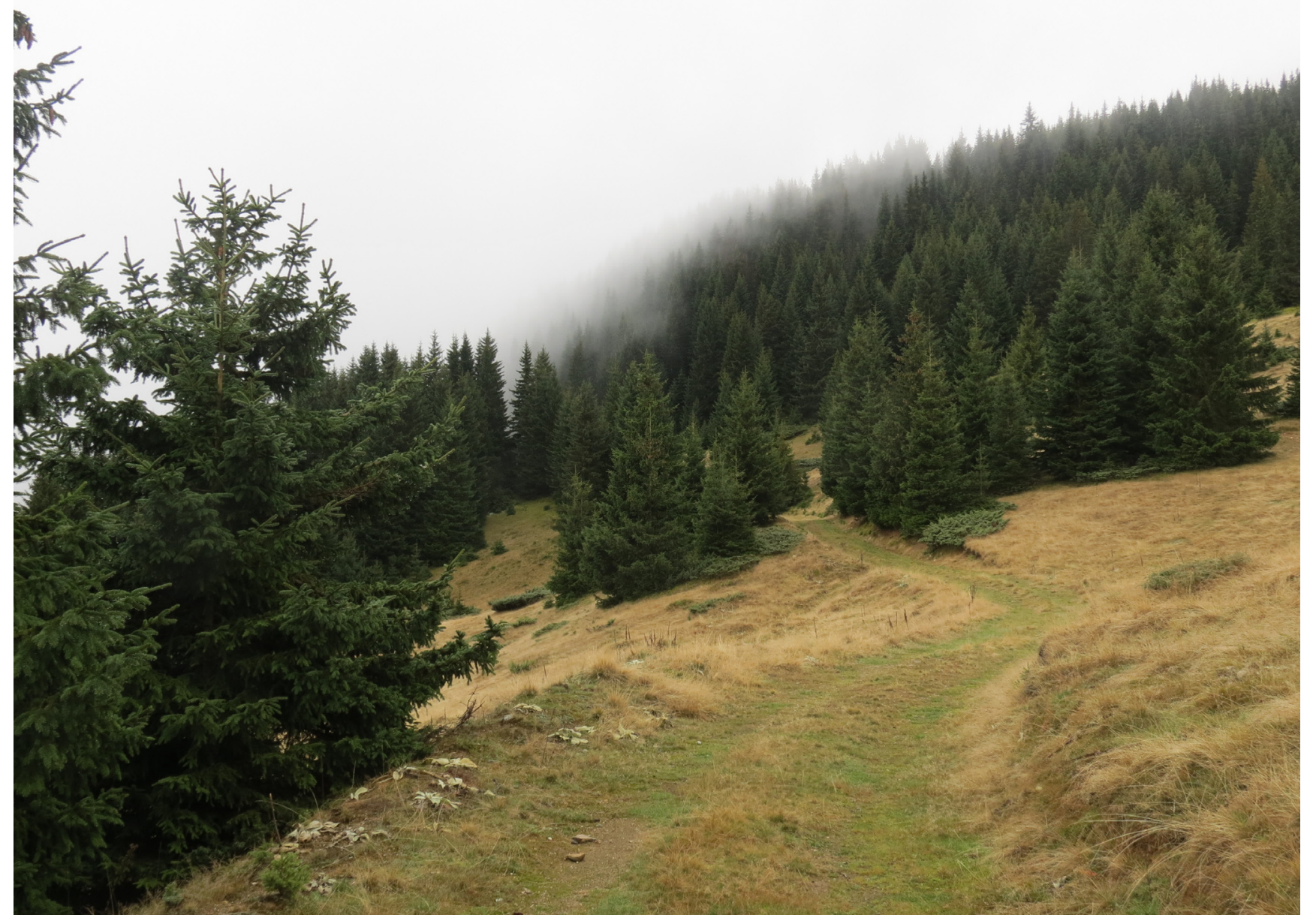

Fig. 1. Habitat of the Tengmalm's owl (Aegolius funereus) in the Central Šar Mts, former Jelak Hut.

owl was heard at 17:17 and again in 17:57, giving 4-5 alarm calls ("tsjalp") very close to us. The owl was observed at moonlight as it flew attacking towards one of us. The habitat was spruce-fir forest, $60-70$ years old, with some much older firs (100-110 years old), situated on a northern slope of the valley. The altitude of the locality was $1572 \mathrm{~m}$ a.s.l. The weather was calm and clear, $7-8^{\circ} \mathrm{C}$. The second Tengmalm's owl in the Adzhina River Valley was heard at 18:43, at $1436 \mathrm{~m}$ a.s.l. It performed three times its alarm call. This locality was at $1.7 \mathrm{~km}$ from the first one in the same valley and in similar habitat, spruce-fir forest.

Until now, for the whole territory of the Republic of Macedonia there has been only an old record from 1919 of one Tengmalm's owl from the mountains close to Skopje (Gengler, 1920; Matvejev \& Vasić, 1973). Later the species was mentioned as a resident bird, possibly distributed in "Serbia and Northern Macedonia" (Vaurie, 1965). The species has not been included in the list of the breeding species of the Republic of Macedonia that is considered for designation of the important bird areas of the country (Velevski et al., 2010). The closest locations in the neighbouring countries are in the Bulgarian part of the Osogovo Mts (Shurulinkov \& Stoyanov, 2005) and in Edessa (Voden) area of Northern Greece (Bauer et al., 1969), probably originating from the Voras Mts (Kaimaktsalan; Gibbons, 2003).

\section{References}

Bauer W., Helversen O., Hodge M., Martens J. 1969 Catalogus faunae Graeciae. Thessaloniki, 203 pp. 


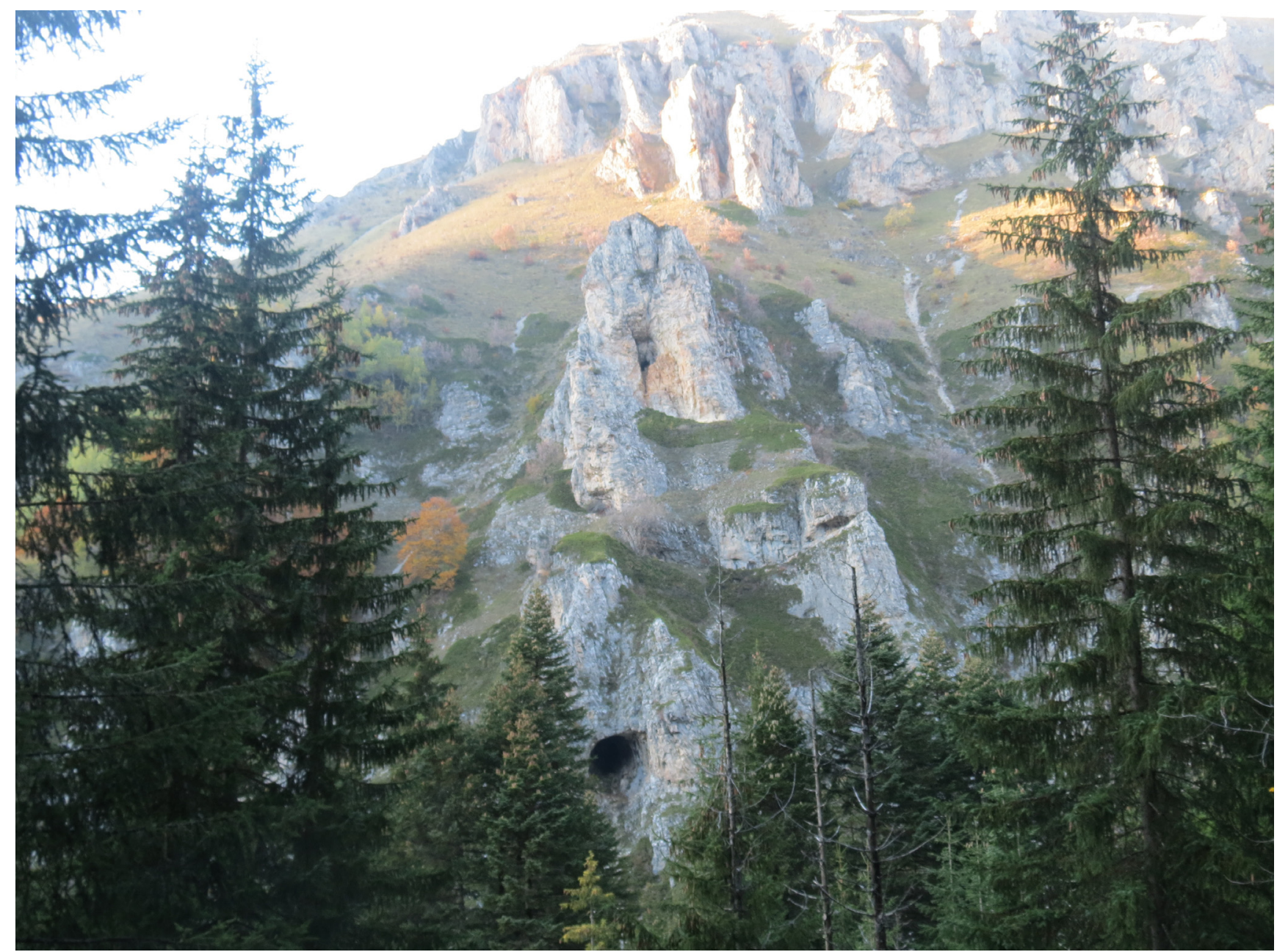

Fig. 2. Habitat of the Tengmalm's owl (Aegolius funereus) in the Southern Šar Mts, Adzhina River.

Delić S. 1948 Ornitološka ekskurzija na Šar-planinu. Larus 2: 102-105. (in Serbian).

Gengler J. 1920 Balkanvögel. Ein ornithologisches Tagebuch. Altenburg, $210 \mathrm{pp}$.

Gibbons B. 2003 Greece. Travellers Nature Guides. Oxford University Press, $328 \mathrm{pp}$.

Kajevska A., Ilić D., Velevski V. 1996 Results of the ornithological survey of Shar Planina Mt. '95. Bulletin of research society of biology students 1 : 63-66. (in Macedonian).

Matvejev S., Vasić V. 1973 Catalogus faunae Yugoslaviae. IV/3 Aves. Ljubljana,117 pp.

Micevski B. 2010 Ornithofauna of the NP Mavrovo. Unpublished report on the project Protection of the environment, economical development and promotion of sustainable ecotourism in Mavrovo National Park - UCODEP: www. oxfamitalia.org/wp-content/uploads/2010/12/ Report-B-MICEVSKI-PRO-MABPOBO-Final25-Nov-2010-g-Angl.pdf.

Rajković D., Grujić D., Novčić R., Mirić R. 2013 Population of Tengmalm's Owl Aegolius funereus in Kopaonik National Park (Central Serbia). Acrocephalus 34 (156-157): 27-32.

Rajković D., Puzović S., Raković M., Grubač B., Simović A., Vučanović M., Đorđević I. 2010 Records of Boreal Owl in Serbia. Ciconia 19: 131140.

Shurulinkov P., Stoyanov G. 2005 New data on the distribution of Tengmalm's Owl (Aegolius funereus) in Western Bulgaria. Buteo 14: 61-66.

Shurulinkov P., Stoyanov G. 2006 Some new findings of Pigmy Owl Glaucidium passerinum and Tengmalm's Owl Aegolius funereus in western and 
southern Bulgaria. Acrocephalus 27 (128-129): $56-68$.

Shurulinkov P., Stoyanov G., Komitov E., Daskalova G., Ralev A. 2012 Contribution to the Knowledge on Distribution, Number and Habitat Preferences of Rare and Endangered Birds in Western Rhodopes Mts., Southern Bulgaria. Strigiformes and Piciformes. Acta Zoologica Bulgarica 64 (1): 43-56.

Trilar T. 1985 Ekskurzija na Šar planino. Acrocephalus 26 (6): 59-65.

Vaurie C. 1965 The birds of the Palearctic fauna. Vol 1. Non-Passeriformes, H. F. \& G. Witherby Ltd., London, 763 pp.
Velevski M., Dimitrovska E., Karchicki V. 2002 Contribution to the ornithofauna of Šar Mts. Bulletin of research society of biology students 2: 153160. (in Macedonian).

Velevski M., Hallman B., Grubać B., Lisicanec T., Stoynov E., Lisicanec E., Avukatov V., Bozić L., Stumberger B. 2010 Important Bird Areas in Macedonia: Sites of Global and European Importance. Acrocephalus 31 (147): 181-282.

Vrezeć A. 2003 Breeding density and altitudinal distribution of the Ural, Tawny and Boreal owls in North Dinaric Alps (central Slovenia). Journal of Raptor Research 37 (1): 55-62. 